\title{
Cytokines and nitric oxide inhibit the enzyme activity of catalase but not its protein or mRNA expression in insulin-producing cells
}

\author{
L A Sigfrid, J M Cunningham, N Beeharry, S Lortz', M Tiedge', S Lenzen', \\ C Carlsson ${ }^{2}$ and I C Green \\ Pharmacy and Biomolecular Sciences, Cockcroft Building, Room 708, University of Brighton, Lewes Road, Brighton BN2 4GJ, UK \\ ${ }^{1}$ Institute of Clinical Biochemistry, Hannover Medical School, D-30623 Hannover, Germany \\ 2Department of Medical Cell Biology, Box 571, University of Uppsala, Biomedicum, 75123 Uppsala, Sweden
}

(Requests for offprints should be addressed to I C Green; Email: i.c.green@ bton.ac.uk)

\begin{abstract}
Pancreatic $\beta$-cells have low activities of the antioxidant enzyme catalase. Nitric oxide interacts with the haem group of catalase inhibiting its activity. We have studied the activity of catalase in $\beta$-cells under conditions mimicking prediabetes and in which nitric oxide is generated from cytokine treatment in vitro. We also studied whether there is regulation of catalase enzyme activity by nitric oxide at the protein or gene expression level. RINm5F insulin-producing cells, treated for $24 \mathrm{~h}$ with cytokines, showed increased medium nitrite production $(17 \pm 2.2$ vs $0.3 \pm 0.2 \mathrm{pmol} / \mathrm{\mu g}$ protein) and significantly decreased cellular catalase activity $(42.4 \pm 4.5 \%)$ compared with control cells. A similar reduction was seen in catalase-overexpressing RIN-CAT cells and in rat or human pancreatic islets of Langerhans. Catalase activity was also suppressed by the long-acting nitric oxide donor diethylenetriamine/nitric oxide adduct (Deta-NO) and this inhibition was reversible. The inhibition of catalase activity by cytokines in RINm5F cells was significantly reversed by the addition of the nitric oxide synthase 2 (NOS2) inhibitors nitro monomethylarginine or $\mathrm{N}$-(3-(aminomethyl)benzyl)acetamidine (1400W). Protein expression was found to be unchanged in cytokine- or Deta-NO-treated RINm5F cells, while mRNA expression was marginally increased. We have shown that inhibition of catalase activity by cytokines is nitric oxide dependent and propose that this inhibition may confer increased susceptibility to cytokine- or nitric oxide-induced cell killing.
\end{abstract}

Journal of Molecular Endocrinology (2003) 31, 509-518

\section{Introduction}

Cytokine treatment of pancreatic islet cells in vitro results in generation of reactive oxygen species (Rabinovitch et al. 1992) and nitric oxide (Southern et al. 1990). In type 1 diabetes mellitus, where islet $\beta$-cells are destroyed, there is evidence of increased cytokine production (Hussain et al. 1996) and formation of peroxynitrite from reactive oxygen species and nitric oxide (Suarez-Pinzon et al. 1997, 2001, Lakey et al. 2001) - these can contribute to cell death by both apoptosis and necrosis (Eizirik et al. 1996, Hadjivassiliou et al. 1998, Hoorens et al. 2001). For reviews on $\beta$-cell death see Mauricio \& Mandrup-Poulsen (1998) and Eizirik \&
Mandrup-Poulsen (2001). Endogenous antioxidant enzymes, which protect against reactive oxygen species, were found to be lower in insulinproducing cells compared with other tissues (Grankvist et al. 1981, Lenzen et al. 1996, Tiedge et al. 1997). It has been shown that overexpression of antioxidant enzymes (Lortz et al. 2000) or the use of inhibitors of nitric oxide production (Hadjivassiliou et al. 1998) protects insulin-producing cells against the harmful effects of certain cytokine or free radical combinations.

Although the effects of cytokine and nitric oxide on many parameters of islet cell function have been studied in the last decade, there are very few reports of their effects on antioxidant enzyme 
activity or expression in insulin-producing cells. Interleukin-1 $\beta$ (IL-1 $\beta$ ) exposure did not affect the activity of catalase in RINm5F cells (Laychock 1998); however, IL-1 $\beta$ treatment of rat islets (Borg et al. 1992) and more recently of purified rat $\beta$-cells (Cardozo et al. 2001b) has been shown to up-regulate the expression of the antioxidant enzyme manganese-superoxide dismutase. De novo synthesis of catalase has been demonstrated to be up-regulated following IL-1 $\beta$ treatment of islets from diabetes-prone BB rats (Sparre et al. 2002). However, the enzyme activity of purified catalase in vitro was inhibited by nitric oxide gas directly (Brown 1995b) and cellular catalase was inhibited by treatment with nitric oxide donors (morpho sydnonimine-1 [SIN-1], s-nitroson-acetyl penicillamine [SNAP]) (Farias-Eisner et al. 1996, Dobashi et al. 1997, Hashida et al. 2000).

The aim of the present work was to investigate the effect of cytokines on catalase activity and its protein and mRNA expression in different types of insulin-producing cells. This was achieved by treating RINm5F cells as well as rat and human islets with cytokines (IL-1 $\beta$, interferon- $\gamma$ (IFN- $\gamma$ ) and tumour necrosis factor- $\alpha(\mathrm{TNF}-\alpha))$. The nitrite and nitrate produced were measured to relate the results to the endogenous production of nitric oxide, and the nitric oxide dependency was studied using inhibitors of nitric oxide generation. The pure nitric oxide donor diethylene traimine/nitric oxide adduct (Deta-NO) was used to treat catalase-overexpressing RINm5F (RIN-Cat) cells to investigate whether overexpression could minimise any inhibitory effects. Alternative sites of the regulation of catalase activity at the protein and mRNA level of catalase were also investigated.

\section{Materials and methods}

\section{Cell culture}

RINm5F tissue culture cells are radiation-induced rat insulinoma cells, originally from the American Type Culture Collection (Gazdar et al. 1980). RIN-Cat cells are RINm5F cells which have been transfected stably with the catalase gene (Tiedge et al. 1997). Cells were grown in RPMI-1640 culture medium containing $11 \mathrm{mmol} / 1$ glucose supplemented with 10\% foetal calf serum (FCS), 1\% L-glutamine $(2 \mathrm{mmol} / \mathrm{l}), 1 \%$ penicillin $(100 \mathrm{IU} / \mathrm{ml})$ and $1 \%$ streptomycin $(100 \mu \mathrm{g} / \mathrm{ml})$. Medium used for RIN-Cat cells was also supplemented with $250 \mu \mathrm{g} / \mathrm{ml}$ genetecin (G418).

\section{Treatment of cell lines}

RINm5F cells were seeded at a density of $4 \times 10^{5}$ cells/well in 12-well plates and RIN-Cat cells were seeded at a density of $2 \times 10^{5}$ cells/well in 24-well plates. After $24 \mathrm{~h}, \mathrm{RIN}$ and RIN-Cat cells were cultured in fresh RPMI medium with Deta-NO (100-500 $\mu \mathrm{mol} / \mathrm{l})$, with a cytokine combination IL- $1 \beta(140 \mathrm{U} / \mathrm{ml})$, IFN- $\gamma(5 \mathrm{U} / \mathrm{ml})$ and TNF- $\alpha$ $(53 \mathrm{U} / \mathrm{ml}) \quad(\mathrm{R} \& \mathrm{D}$ Systems (Europe Ltd), Abingdon, UK), or left untreated as controls. The cytokine doses chosen were those which allowed the cells to generate nitric oxide sufficient to have biological effects but not to cause cell detachment and death. After $24 \mathrm{~h}$, nitrite was determined in the cell media using the modified Griess assay (Green et al. 1982) and nitrate was converted to nitrite using nitrate reductase essentially as described elsewhere (Mabley et al. 2002). In some experiments, cytokine production of nitric oxide was blocked, using two different inhibitors of nitric oxide synthase 2. NMMA ( $\mathrm{N}^{\mathrm{G}}$ monomethyl-1arginine monoacetate salt) $(500 \mu \mathrm{mol} / \mathrm{l})$ (Calbiochem, Nottingham, UK) and 1400W (100 $\mathrm{mol} / \mathrm{l})$ N-(3-(Aminomethyl)benzyl)acetamidine (SigmaAldrich, Poole, UK) were added simultaneously with cytokines into RPMI culture medium containing arginine. For catalase activity assay, cells were trypsinised, washed twice in phosphate-buffered saline (PBS) and spun at $188 \boldsymbol{g}$ for $5 \mathrm{~min}$ at $4{ }^{\circ} \mathrm{C}$. PBS was removed and the cell pellet resuspended in $300 \mu \mathrm{l}$ phosphate buffer $(25 \mathrm{mmol} / \mathrm{l}, \mathrm{pH} 7 \cdot 00)$. Cell samples were frozen at $-70{ }^{\circ} \mathrm{C}$, thawed and sonicated (10 s, probe 3, 50\%, ultrasonic processor XL; Heat Systems, NY, USA) on ice, prior to being assayed for catalase activity (Johansson \& Borg 1988). Protein samples were made alkaline and assayed using the Bradford (1976) assay.

\section{Rat and human islets of Langerhans}

Islets of Langerhans were isolated from Wistar rats by digesting the pancreatic tissue with collagenase (Hadjivassiliou et al. 2000). Islets were incubated in six-well plates at $37^{\circ} \mathrm{C}$ in a humidified atmosphere of $95 \%$ air $/ 5 \% \mathrm{CO}_{2}$ for $48 \mathrm{~h}$ before treatment. Human islets were obtained from the Department of Surgery, University of Leicester, Leicester, UK 
and cultured in RPMI-1640 tissue culture medium containing $5.5 \mathrm{mmol} / \mathrm{l}$ glucose, $50 \mathrm{U} / \mathrm{ml}$ penicillin, $50 \mu \mathrm{g} / \mathrm{ml}$ streptomycin, $2 \mathrm{mmol} / \mathrm{l}$ L-glutamine and 5\% FGS (Hadjivassiliou et al. 1998). Rat islets were cultured in RPMI-1640 containing $11 \mathrm{mmol} / \mathrm{l}$ glucose, $100 \mathrm{U} / \mathrm{ml}$ penicillin, $100 \mu \mathrm{g} / \mathrm{ml}$ streptomycin, $2 \mathrm{mmol} / \mathrm{l}$ L-glutamine and $10 \%$ FCS.

Human islets were treated for $48 \mathrm{~h}$ with IL-1 $\beta$ $(140 \mathrm{U} / \mathrm{ml}), \mathrm{IFN}-\gamma(1000 \mathrm{U} / \mathrm{ml}), \mathrm{TNF}-\alpha(53 \mathrm{U} / \mathrm{ml})$ or Deta-NO $(250 \mu \mathrm{mol} / \mathrm{l})$. Rat islets were treated with IL- $1 \beta(140 \mathrm{U} / \mathrm{ml}), \mathrm{IFN}-\gamma(5 \mathrm{U} / \mathrm{ml})$ and TNF- $\alpha$ $(53 \mathrm{U} / \mathrm{ml})$ for $24 \mathrm{~h}$. Islets were transferred with a plastic pipette into Eppendorf tubes $(1.5 \mathrm{ml})$, washed twice in PBS and pelleted at $200 \boldsymbol{g}$. Phosphate buffer $(300 \mu \mathrm{l} ; 25 \mathrm{mmol} / \mathrm{l})$ was added. The islet samples were frozen at $-70{ }^{\circ} \mathrm{C}$, thawed and sonicated for $10 \mathrm{~s}$ (as above) on ice, prior to being assayed for catalase activity.

\section{Catalase activity assay}

The activity of catalase (E.C. 1.11.1.6) was measured by a sensitive spectrophotometric method (Johansson \& Borg 1988). This method utilises the peroxidatic function of catalase with methanol as the hydrogen donor and the production of formaldehyde is determined with purpald (4-amino-3-hydrazino-5-mercapto-1,2,4triazole) as a chromogen. Samples of tissue homogenates, blanks or formaldehyde standards were incubated in duplicate with $5.9 \mathrm{~mol} / \mathrm{l}$ methanol and $4.2 \mathrm{mmol} / \mathrm{l}$ hydrogen peroxide in a $250 \mathrm{mmol} / 1$ phosphate buffer, $\mathrm{pH} 7 \cdot 0$, for $20 \mathrm{~min}$ at room temperature $\left(20^{\circ} \mathrm{G}\right)$. After termination of the enzymatic reaction with a $7.8 \mathrm{~mol} / 1$ potassium hydroxide solution, a second incubation with purpald was performed for $10 \mathrm{~min}$ at $20^{\circ} \mathrm{C}$. To obtain a coloured compound, the product of the reaction between formaldehyde and purpald was oxidised by potassium periodate. The absorbance was measured at $540 \mathrm{~nm}$.

\section{Western blotting}

RINm5F cells were treated for $24 \mathrm{~h}$ with a combination of three cytokines $(140 \mathrm{U} / \mathrm{ml}$ IL- $1 \beta$, $53 \mathrm{U} / \mathrm{ml} \mathrm{TNF}-\alpha$ and $5 \mathrm{U} / \mathrm{ml} \mathrm{IFN}-\gamma$ ) or $250 \mu \mathrm{mol} / \mathrm{l}$ Deta-NO and were prepared for electrophoresis and Western blotting as described previously (Mabley et al. 1997). The protein content was determined (Bradford 1976) and gel lanes were equiloaded. The samples were separated on a 7.5\% polyacrylamide gel (SDS-PAGE) and blotted onto a polyvinylidene difluoride membrane (pore size $0.45 \mu \mathrm{m}$ ) (Mabley et al. 1997). Catalase was detected after incubation overnight at $4{ }^{\circ} \mathrm{C}$ in the primary antibody (1:1000 dilution; polyclonal anti-human catalase antibody raised in rabbit; CN Biosciences UK, Beeston, Notts, UK). The incubation with the secondary antibody goat anti-rabbit $\operatorname{IgG} \quad(\mathrm{H}=\mathrm{L})$-horseradish peroxidase conjugate (1:1000 dilution; Bio-Rad Laboratories, Hemel Hempstead, Herts, UK) was for $1 \mathrm{~h}$ at room temperature. The proteins were visualised using an enhanced chemiluminescence (ECL) kit from Pierce, Rockford, IL, USA (Mabley et al. 1997). The integrated density values (IDV) were determined using Imagemaster software 'Alphaease' (Alpha Innotech Corp, Cannock, UK) for the catalase band in RINm5F cells treated with a combination of cytokines or Deta-NO.

\section{RNA isolation from islets and cell lines}

RNA was isolated from islets and cell lines using modifications of the acid guanidinium thiocyanatephenol-chloroform extraction methods originally described by Chomczynski \& Sacchi (1987). A minimum of 200 islets was extracted using TriReagent (and the protocol of Sigma-Aldrich Chemical Co., Poole, UK). Isopropanol $(0.5 \mathrm{ml})$ was added to the RNA from the top aqueous layer and the tubes were mixed and incubated for $1-24 \mathrm{~h}$ at $-20{ }^{\circ} \mathrm{C}$. After incubation, the tubes were spun at $14000 \mathrm{~g}$ for $20 \mathrm{~min}$ at $4^{\circ} \mathrm{C}$, the supernatant discarded and $1 \mathrm{ml}$ ethanol $(75 \%)$ added for each $1 \mathrm{ml}$ TriReagent used. The tubes were spun at $14000 \mathrm{~g}$ for $15 \mathrm{~min}$ at $4{ }^{\circ} \mathrm{C}$, the supernatant was discarded and the ethanol wash step repeated. All of the supernatant was finally removed and the pellets dried at room temperature; RNA samples were stored at $-70{ }^{\circ} \mathrm{C}$. The quality and concentration of the RNA were measured by the $260 / 280$ ratio and only samples with ratios above 1.5 were used in the experiments.

RINm5F cells seeded at $8 \times 10^{5}$ cells/well in six-well plates were preincubated for $24 \mathrm{~h}$ at $37^{\circ} \mathrm{C}$ and then left as controls or treated with a combination of three cytokines $(140 \mathrm{U} / \mathrm{ml}$ IL-1 $\beta$, $5 \mathrm{U} / \mathrm{ml} \mathrm{IFN}-\gamma$ and $53 \mathrm{U} / \mathrm{ml} \mathrm{TNF}-\alpha)$ or $250 \mu \mathrm{mol} / 1$ 
Deta-NO. RNAzol B (1 ml) (AMS Biotechnology (Europe) Ltd) was added to all wells to lyse and detach the cells. The cell lysate was passed through a pipette tip a few times to solubilise the RNA and the lysate was transferred to $1.5 \mathrm{ml}$ tubes. Chloroform $(0 \cdot 1 \mathrm{ml})$ was added to each tube and the samples shaken vigorously for $15 \mathrm{~s}$ and put on ice for $5 \mathrm{~min}$, before being spun at $12000 \boldsymbol{g}$ for $15 \mathrm{~min}$ at $4{ }^{\circ} \mathrm{C}$. The aqueous upper phase was transferred carefully to new tubes for RNA precipitation and handling as for islets (above).

\section{cDNA synthesis}

All RNA samples were DNase treated using RQ1 RNase-free DNase (Promega, Southampton, Hants, UK). cDNA was synthesised from the RNA samples using the reverse IT 1st strand synthesis kit (ABgene, Epsom, Surrey, UK). An MS2-positive control RNA (50 $\mathrm{ng} / \mu \mathrm{l})$ and MS2 primers supplied in the kit were used as a positive control. A negative 'no reverse transcription' control was performed by omitting the reverse transcriptase blend in one cDNA sample to check for any DNA contamination in the RNA samples. RNA from islets $(1 \mu \mathrm{g})$ or $2 \mu \mathrm{g}$ from cells was used. All incubations were performed in a TouchDown thermal cycler (Hybaid Ltd, Ashford, Kent, UK). The cDNA samples were stored at $-70{ }^{\circ} \mathrm{C}$.

\section{Quantitative RT-PCR using the LightCycler system}

cDNA was constructed from $2 \mu \mathrm{g}$ RINm5F RNA as described above. Real-time PGR was carried out on the iGycler iQ Real Time PGR detection system using primers designed by Tib Molbiol, Berlin, Germany. SYBR Green I was used as the fluorescent dye. The results for mRNA expression in RINm5F cells were related to glucose-6phosphate dehydrogenase (G6PDH) as the housekeeper gene. Catalase primer P1: CTGTGTGA GAACATTGCGAACCACG; catalase P2: CGA GGCTGTGAGGTAACATAAGACT; G6PDH P1: ATTGACGACTACGTGGGGAA; G6PDH P2: GAGATAGAGTTGAAGAGTTTGACGT. The relative quantities of PGR product to the housekeeping gene were calculated following the manufacturer's recommended method using the cycle threshold (CT) values (CT represents the PGR cycle at which a significant increase in

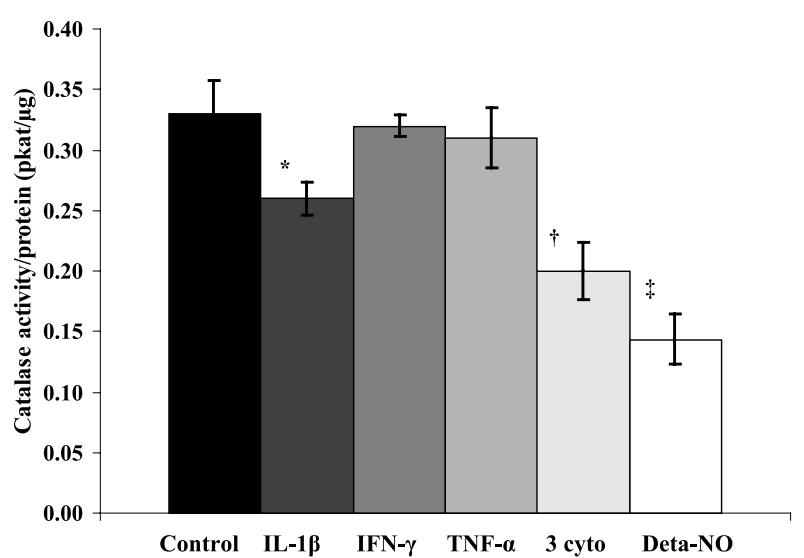

Figure 1 Catalase activity in RINm5F cells after $24 \mathrm{~h}$ of cytokine or Deta-NO treatment. RINm5F cells were seeded at $4 \times 10^{5}$ cells/well in 12-well plates and after $24 \mathrm{~h}$ were treated with IL-1 $\beta(140 \mathrm{U} / \mathrm{ml}), \mathrm{IFN}-\gamma(5 \mathrm{U} / \mathrm{ml})$ and TNF- $\alpha$ (53 U/ml), singly and in combination (3 cyto), with $500 \mu \mathrm{mol} / \mathrm{l}$ Deta-NO or were left untreated as control cells, for another $24 \mathrm{~h}$. Cell samples were frozen, sonicated, assayed for catalase activity and protein was determined using the Bradford assay. Catalase activity was determined as pkat/ $\mu \mathrm{g}$ protein and is expressed as means \pm S.E.M. Treatment with IL-1 $\beta$ $(140 \mathrm{U} / \mathrm{ml})$ on its own or in combination with TNF- $\alpha$ and IFN- $\gamma$ or Deta-NO for $24 \mathrm{~h}$ significantly inhibited catalase activity related to protein content in RINm5F versus control cells, ${ }^{\star} \ddagger P<0.01, n=4$, one-way ANOVA.

fluorescence above the baseline is first detected). The mean change in CT was calculated from differences between the CT for gene of interest and houskeeping gene for control, treated or experimental groups. Relative quantification values are expressed as 2 (-delta CT) see also http:// www.lightcycler-online.com.

\section{Results}

To study the effect of cytokines on catalase activity on insulin-producing cells, RINm5F cells, catalaseoverexpressing RINm5F cells, rat and human islets were treated with a combination of IL- $1 \beta$, IFN- $\gamma$ and/or TNF- $\alpha$ for $24 \mathrm{~h}$. Treatment with IL- $1 \beta$ on its own significantly inhibited catalase activity in RINm5F cells by $20 \%$, while IFN- $\gamma$ and TNF- $\alpha$ were without effect (Fig. 1). Treatment with a combination of cytokines - IL- $1 \beta$, TNF- $\alpha$ and IFN- $\gamma$ - inhibited catalase activity by $40 \%$ in RINm5F cells (Fig. 1). Cytokine treatment resulted in induction of nitric oxide synthase and 
intracellular production of nitric oxide in RINm5F cells and islets of Langerhans. We tested whether a specific nitric oxide donor inhibited catalase activity and found that Deta-NO $(250 \mu \mathrm{mol} / \mathrm{l})$ treatment for $24 \mathrm{~h}$ reduced catalase activity by $55 \%$ in RINm5F versus control cells (Fig. 1).

The addition of NOS2 inhibitors confirmed that the inhibition of catalase activity by cytokines was due to nitric oxide. Treatment with nitro monomethylarginine (NMMA) or 1400W significantly reversed cytokine inhibition of catalase activity in RINm5F cells (Fig. 2a) and decreased nitric oxide production (Fig. 2b). Previously we have used NOS2 inhibitors in arginine-free medium to ensure elimination of measurable nitric oxide production. Under those conditions, treatment of RINm5F cells with NMMA - on its own or with cytokines resulted in unexpected inhibition of catalase activity to $65 \%$ and $50 \%$ respectively compared with untreated cells $(P<0 \cdot 01, n=3$, data not shown). The NMMA effect on catalase activity was, however, insignificant in arginine-containing medium (Fig. 2a); this, together with data from the more selective inhibitor of NOS2 (1400W) enabled clear conclusions to be drawn about the nitric oxide dependency of cytokine inhibition of catalase activity.

IL- $1 \beta$, TNF- $\alpha$ and IFN- $\gamma$ also inhibited catalase activity significantly by $30 \%$ in human islets and by $46 \%$ in rat islets (Fig. 3); Deta-NO inhibited catalase activity by $40 \%$ in human islets versus untreated islets (Fig. 3), indicating that primary tissue enzyme was similarly susceptible to nitric oxide-mediated inhibition.

A combination of cytokines also inhibited catalase activity by $60 \%$ in catalase-overexpressing RINm5F cells (RIN-Cat) versus untreated cells (Fig. 4) (note the y axis levels of catalase). Deta-NO treatment for $24 \mathrm{~h}$ inhibited catalase activity by $50 \%$ in RIN-Cat versus control cells (Fig. 4). The inhibitory effect of Deta-NO on catalase activity in RINm5F cells was reversible after a short time exposure. RINm5F cells were treated with $250 \mu \mathrm{mol} / 1$ Deta-NO for $30 \mathrm{~min}$ which significantly reduced enzyme activity (control $0 \cdot 22 \pm 0 \cdot 01$ vs Deta-NO $0 \cdot 15 \pm 0 \cdot 01 \mathrm{pkat} / \mu \mathrm{g}$ protein; $P<0 \cdot 05$, $n=3$, ANOVA). Cells were restored to normal culture media after the $30-\mathrm{min}$ treatment and, when re-examined after $24 \mathrm{~h}$, catalase activity had recovered significantly to $0.25 \pm 0.03 \mathrm{pkat} / \mu \mathrm{g}$ protein $(P<0 \cdot 05, n=3)$ - a value which was not different from the 24-h control value.
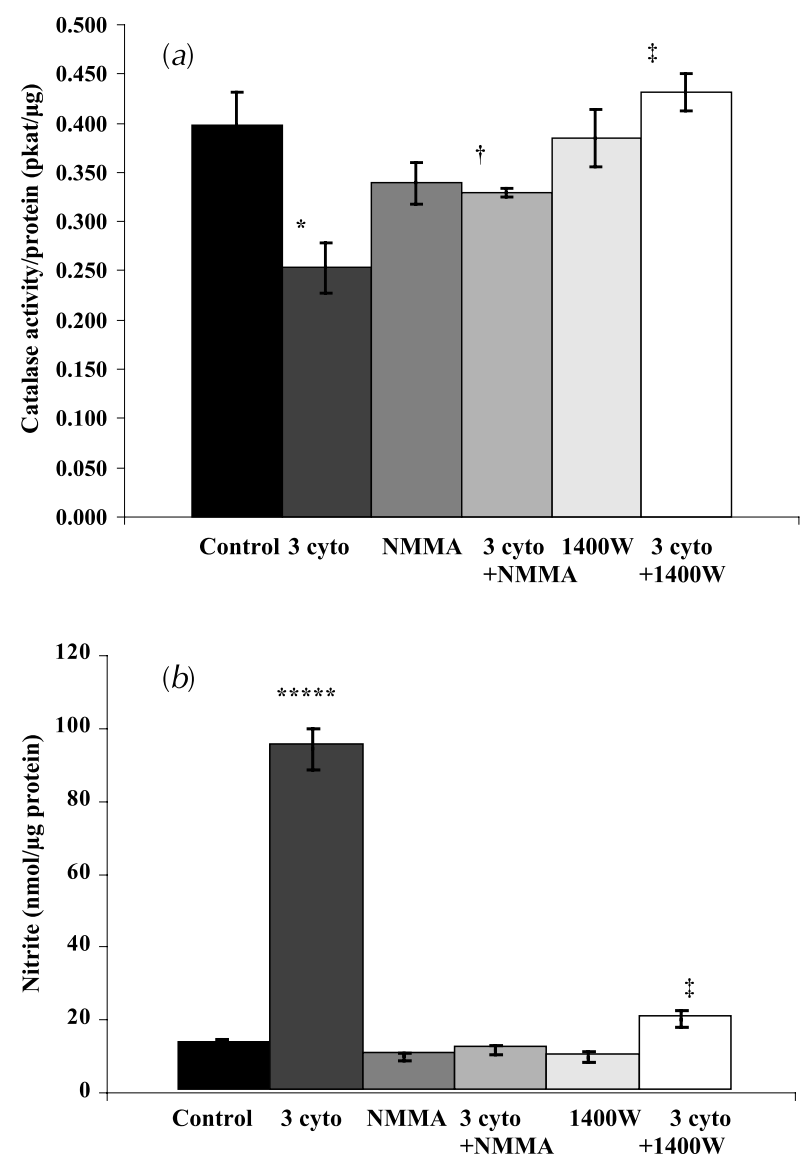

Figure 2 (a) Catalase activity and (b) nitrite production in RINm5F cells after treatment with cytokines (3 cyto) and NOS2 inhibitors. RINm5F cells were seeded at $4 \times 10^{5} \mathrm{cells} /$ well in 12 -well plates and after $24 \mathrm{~h}$ were treated with IL-1 $\beta$, IFN- $\gamma$ and TNF- $\alpha$ (as in Materials and methods). Cells were also treated with NMMA (500 $\mu \mathrm{mol} / \mathrm{l})$ or $1400 \mathrm{~W}(100 \mu \mathrm{mol} / \mathrm{l}) \pm$ cytokines for another $24 \mathrm{~h}$. Cells were harvested, and pellets were frozen, sonicated and extracts assayed for catalase activity and protein (a). Catalase activity is shown as mean pkat/ug protein \pm S.E.M. Treatment with a combination of the three cytokines significantly inhibited catalase activity compared with no treatment, ${ }^{\star} P<0.01, n=6$. The cytokine inhibiton of catalase activity was significantly reversed by the addition of NOS2 inhibitors NMMA or $1400 \mathrm{~W}$, which had no significant effect on their own, ${ }^{\dagger \ddagger} P<0.01, n=6$. (b) Nitrite in the medium was assayed; cytokine stimulation of nitrite production was significantly reversed by NMMA, ${ }^{\star \star \star \star \star} P<0.00001$ and by $1400 \mathrm{~W},{ }^{\ddagger} P<0.03$. Statistical analysis was by one-way ANOVA.

\section{Nitrite and nitrate produced from cytokine-treated RINm5F and RIN-Cat cells}

There was a dramatic rise in nitrite produced from RINm5F cells or RIN-Cat cells cultured in the 


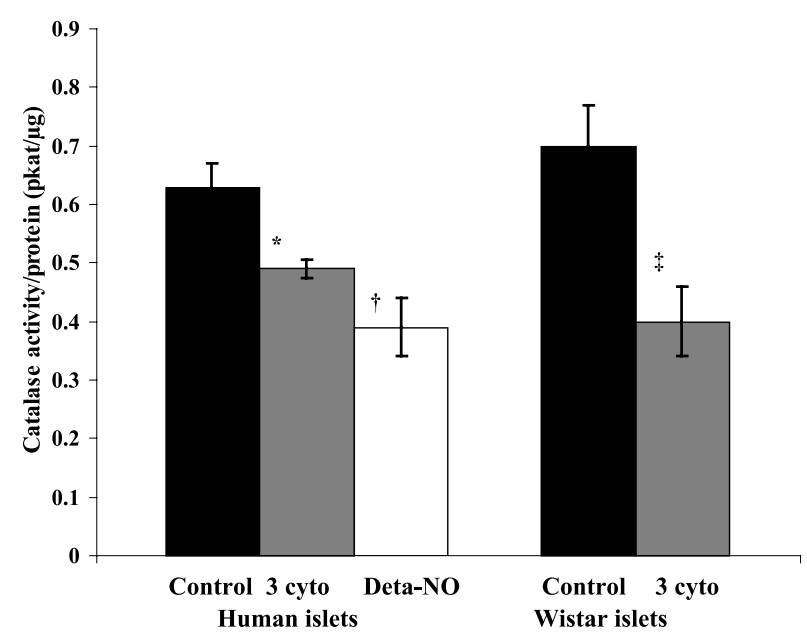

Figure 3 Catalase activity in human and rat islets after $24 \mathrm{~h}$ of cytokine or Deta-NO treatment. Human or rat islets were cultured for 2 days. Human islets were then treated with IL-1 $\beta(140 \mathrm{U} / \mathrm{ml})$, IFN- $\gamma(1000 \mathrm{U} / \mathrm{ml})$ and TNF- $\alpha(53 \mathrm{U} / \mathrm{ml})$ (3 cyto), with $250 \mu \mathrm{mol} / \mathrm{l}$ Deta-NO or left untreated as control islets. Rat islets were treated with IL-1 $\beta(140 \mathrm{U} / \mathrm{ml})$, IFN- $\gamma(5 \mathrm{U} / \mathrm{ml})$ and TNF- $\alpha$ $(53 \mathrm{U} / \mathrm{ml})$ for $24 \mathrm{~h}$ or left untreated as control islets. Islets samples were frozen, sonicated and assayed for catalase activity, and protein was measured using the Bradford assay. Data are expressed as means \pm S.E.M. Treatment with cytokines or Deta-NO for $24 \mathrm{~h}$ resulted in decreased catalase activity related to protein content in human islets, ${ }^{*}{ }^{*} P<0.01$ versus untreated islets, $n=3$. Treatment with the three cytokines also decreased catalase activity in rat islets, ${ }^{\ddagger} P<0.01$ vs control islets, $n=3$. Statistical analysis was by one-way ANOVA.

presence of either IL-1 $\beta$ on its own or a cytokine mix, but not in the presence of either IFN- $\gamma$ or TNF- $\alpha$ alone (Table 1). More nitrite was produced in media from IL-1 $\beta$ - and cytokine-treated RIN-Cat (70 and $73 \%$ respectively) versus RINm5F cells. However, 54\% more nitrate was produced in media from cytokine-treated RINm5F versus RIN-Cat cells and $70 \%$ more nitrate was produced in media from IL- $1 \beta$-treated RINm5F versus RIN-Cat cells. There were no significant differences in total nitrite plus nitrate production between RINm5F and RIN-Cat cells after treatment with a combination of cytokines (Table 1).

\section{Protein and mRNA expression of catalase in cytokine- or Deta-NO-treated RINm5F cells}

There were no significant differences in the protein expression of catalase, as determined by Western blotting (Fig. 5) after treatment of RINm5F cells with

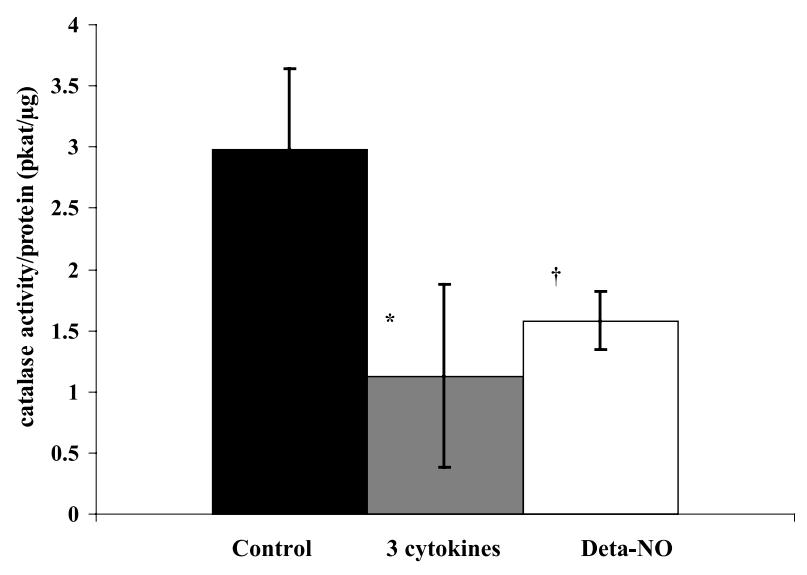

Figure 4 Catalase activity in RIN-Cat cells after $24 \mathrm{~h}$ of cytokine or Deta-NO treatment. Catalase-overexpressing RIN-Cat cells were seeded at $2 \times 10^{5}$ cells/well in 24-well plates for $24 \mathrm{~h}$ and treated with IL-1 $\beta$ (140 U/ml), IFN- $\gamma$ $(5 \mathrm{U} / \mathrm{ml})$ and TNF- $\alpha(53 \mathrm{U} / \mathrm{ml})$, with $100 \mu \mathrm{mol} / \mathrm{l}$ Deta-NO or left untreated as control cells. After another $24 \mathrm{~h}$, cells were trypsinised, sonicated, frozen and assayed for catalase activity. Protein was measured using the Bradford assay. Values are expressed as means \pm S.E.M. Cytokines or Deta-NO significantly inhibited catalase activity related to protein content after $24 \mathrm{~h}$ in RIN-Cat cells, ${ }^{\star \dagger} P<0.01$ versus untreated, $n=3$, one-way ANOVA.

a combination of cytokines (IL-1 $\beta$, IFN- $\gamma$ and TNF- $\alpha)$ or with Deta-NO $(250 \mu \mathrm{mol} / \mathrm{l})$ for $24 \mathrm{~h}$. The IDV of Western blot bands was as follows: untreated RINm5F cells $(12894 \pm 1218$ IDV), cytokinetreated (12 $986 \pm 1617 \mathrm{IDV})$ and Deta-NO treated (16 $199 \pm 2532$ IDV). There were no significant differences in the mRNA expression of catalase in RINm5F cells after treatment with IL- $1 \beta$, IFN- $\gamma$ and TNF- $\alpha$ or Deta-NO $(250 \mu \mathrm{mol} / \mathrm{l})$ for $24 \mathrm{~h}$ compared with untreated cells (Fig. 5). For cytokine treatment, three out of four experiments showed a significant increase (approximately threefold) in mRNA expression for catalase relative to G6PDH, but the fourth experiment showed a slight decrease causing the cytokine effect to be non-significant statistically for a variety of analyses including ANOVAs of $\log$ transformed raw data. If the effect of cytokines on catalase are expressed relative to controls set at $100 \%$, there was significantly more mRNA for catalase in cytokine-treated cells.

\section{Discussion}

Cytokine treatment results in free radical formation and changes in gene (Cardozo et al. 2001a) and 
Table 1 Nitrite and combined nitrite and nitrate in minimum essential media (MEM) from RINm5F and RIN-Cat cells after cytokine treatment. Nitrite or nitrite and nitrate produced in the media from cytokine-treated RINm5F and $\mathrm{RIN}$-Cat cells are expressed related to protein content $(\mathrm{pmol} / \mu \mathrm{g})$. RINm5F and RIN-Cat cells were treated with individual cytokines or a combination of cytokines (IL-1 $\beta$ (140 U/ml), IFN- $\gamma(5 \mathrm{U} / \mathrm{ml})$ and/or TNF- $\alpha$ (53 U/ml) (three cytokines)) for $24 \mathrm{~h}$ in MEM (no nitrate) plus supplements. Nitrite and nitrate were measured using the modified Griess assay (Green et al. 1982). Protein was measured using the Bradford assay. Values are expressed as means \pm S.E.M.

\begin{tabular}{|c|c|c|c|c|c|c|}
\hline & \multicolumn{2}{|c|}{$\begin{array}{l}\text { Nitrite/protein } \\
(\mathrm{pmol} / \mu \mathrm{g})\end{array}$} & \multicolumn{2}{|c|}{$\begin{array}{l}\text { Nitrate/protein } \\
(\mathrm{pmol} / \mu \mathrm{g})\end{array}$} & \multicolumn{2}{|c|}{$\begin{array}{l}\text { Total nitrite and nitrate } \\
(\mathrm{pmol} / \mu \mathrm{g})\end{array}$} \\
\hline & RIN-Cat & RINm5F & RIN-Cat & RINm5F & RIN-Cat & RINm5F \\
\hline $\begin{array}{l}\text { Control } \\
\text { IL-1 } \beta \\
\text { IFN- } \gamma \\
\text { TNF- } \alpha \\
\text { Three cytokines }\end{array}$ & $\begin{array}{c}3 \pm 1 \cdot 2 \\
53 \pm 22 \cdot 5 \\
2 \pm 1 \cdot 0 \\
4 \pm 1 \cdot 6 \\
63 \pm 25 \cdot 6^{a}\end{array}$ & $\begin{array}{r}0 \cdot 3 \pm 0 \cdot 2 \\
17 \pm 3 \cdot 3 \\
1 \pm 0 \cdot 5 \\
1 \pm 1 \cdot 2 \\
17 \pm 2 \cdot 2\end{array}$ & $\begin{array}{c}1 \pm 0 \cdot 7 \\
35 \pm 15 \cdot 7 \\
0 \pm 0 \\
0 \cdot 4 \pm 0 \cdot 4 \\
56 \pm 21 \cdot 2\end{array}$ & $\begin{array}{c}3 \pm 1 \cdot 4 \\
116 \pm 26 \cdot 3^{\mathrm{c}} \\
3 \pm 2 \cdot 2 \\
6 \pm 3 \cdot 6 \\
122 \pm 17 \cdot 8^{\mathrm{b}}\end{array}$ & $\begin{array}{c}2 \pm 1 \cdot 7 \\
106 \pm 32 \cdot 8 \\
1 \pm 0 \cdot 8 \\
0 \cdot 5 \pm 0 \cdot 31 \\
129 \pm 45 \cdot 3\end{array}$ & $\begin{array}{c}2 \cdot 5 \pm 1 \cdot 25 \\
133 \pm 29 \cdot 4 \\
3 \pm 2 \cdot 2 \\
7 \pm 4 \cdot 7 \\
139 \pm 19 \cdot 9\end{array}$ \\
\hline
\end{tabular}

There was significantly more nitrite produced in the media from the three cytokine-treated RIN-Cat cells vs RINm5F cells, ${ }^{a} P<0.05$, $n=4$, but significantly more nitrate was produced in the media from the three cytokine-treated RINm5F vs RIN-Cat cells, b $P<0 \cdot 05$, $n=3$ and in the media from IL-1 $\beta$-treated RINm5F vs RIN-Cat cells, ${ }^{c} P<0 \cdot 05, n=3$. There were no differences in nitrite plus nitrate between RINm5F and RIN-Cat cells after any treatment. Student's $t$-test was used.

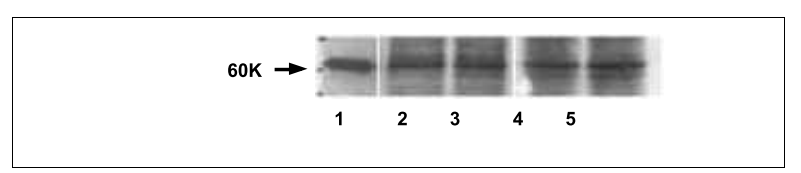

\begin{tabular}{|l|l|l|l|}
\hline Mean \pm SEM & Control & 3 cytokines & Deta-NO \\
\hline $\begin{array}{l}\text { Protein: Integrated } \\
\text { density value (IDV) }\end{array}$ & $12894 \pm 1218$ & $12986 \pm 1617$ & $16199 \pm 2532$ \\
\hline $\begin{array}{l}\text { mRNA Cycle threshold } \\
\left(2^{(-\triangle C T)}\right)\end{array}$ & $6.2 \pm 1.84$ & $17.6 \pm 7.07$ & $9.5 \pm 2.5$ \\
\hline
\end{tabular}

Figure 5 Catalase protein and mRNA expression in RINm5F cells treated with the three cytokines or Deta-NO. RINm5F cells were cultured in RPMI-1640 media to $70 \%$ confluency in six-well plates, treated for $24 \mathrm{~h}$ with a combination of cytokines $(140 \mathrm{U} / \mathrm{ml} \mathrm{IL}-1 \beta$, $53 \mathrm{U} / \mathrm{ml}$ TNF- $\alpha$ and $5 \mathrm{U} / \mathrm{ml}$ IFN- $\gamma$ ), $250 \mu \mathrm{mol} / \mathrm{I}$ Deta-NO or left untreated as control cells. Cell protein extracts $(20 \mu \mathrm{g})$ were loaded per well; a polyclonal catalase antibody and ECL detection were used. Lane 1: purified catalase $(0.1 \mathrm{ng}) \mathrm{RINm} 5 \mathrm{~F}$ cell extracts; lane 2: untreated cells; lane 3: cytokine treated; lane 4: untreated cells; lane 5: DETA-NO treated. RNA was extracted using a chloroform-phenol extraction protocol and cDNA was synthesised from $2 \mu \mathrm{g}$ RNA and quantified using the LightCycler system. Data are expressed as means \pm S.E.M., $n=4$ experiments; catalase expression levels are corrected relative to expression of G6PDH. Statistical analysis was by one-way ANOVA. There were no significant differences in either mRNA or protein expression of catalase after treatments, although there was a significant difference $(P<0.049)$ for increased catalase mRNA if the data for four experiments are converted to percentage of control (set at $100 \%$ ). protein expression (John et al. 2000, Mose Larsen et al. 2001) of 'harmful' and 'protective' proteins in $\beta$-cells. Our work has shown that a previously unreported potentially harmful action of cytokines is inhibition of an existing antioxidant defence. Thus, IL- $1 \beta$ treatment, which is known to increase reactive oxygen (Pociot et al. 1993), as well as nitrogen species (Lindsay et al. 1997, Suarez-Pinzon et al. 1997), lowers the activity of catalase in insulin-producing cells. A combination of cytokines (IL-1 $\beta$, IFN- $\gamma$ and TNF- $\alpha$ ) further inhibited catalase activity, not only in RINm5F cells but also in catalase-overexpressing RINm5F cells and in rat and human islets of Langerhans.

The low affinity of catalase for its substrate hydrogen peroxide favours the detoxification of high concentrations of this toxin. Under situations of cellular stress with a concomitant deterioration of oxidative metabolism, high amounts of hydrogen peroxide could be formed, e.g. in the vicinity of the mitochondria due to rapid dismutation of superoxide radicals. Studies in insulin-producing RINm5F cells overexpressing glutathione peroxidase revealed that glutathione peroxidase cannot compensate for low expression levels of catalase in the detoxification of hydrogen peroxide (Lenzen et al. 1996, Tiedge et al. 1997, Grankvist et al. 1981). Thus, in insulin-producing cells, the inactivation of catalase by nitric oxide may weaken the antioxidative defence status resulting in cell death by necrosis and apoptosis. 
The NOS2 inhibitors - NMMA and 1400W were used to demonstrate whether inhibition of catalase activity by cytokines was due to nitric oxide production. The arginine analogue NMMA was used in arginine-free medium initially but conclusions could not be drawn about nitric oxide mediation of the cytokine effect on catalase activity since NMMA, on its own, inhibited catalase activity in RINm5F cells. NMMA has been found to inhibit catalase activity in brain cells (Rotzinger et al. 1995, Barthwal et al. 2000). There is a possible mechanism for this effect of NMMA in arginine-free medium, i.e. NOS2 produces superoxide when the arginine concentration is low (Xia \& Zweier 1997) and the superoxide produced has been reported to inhibit catalase (Halliwell \& Gutteridge 1999). However, in normal RPMI medium, NMMA alone did not significantly lower catalase activity and reversed the cytokine inhibition of activity. Use of $1400 \mathrm{~W}$ (Garvey et al. 1997) convincingly confirmed that nitric oxide mediated the cytokine inhibition.

An alternative strategy to see if nitric oxide inhibited catalase activity in insulin-producing cells was to use a chemical nitric oxide donor. We found that the specific and longer acting nitric oxide donor Deta-NO inhibited catalase activity in RINm5F cells, rat islets and human islets to the same extent as cytokines. These findings are in agreement with previous studies using catalase from other cell types. Nitric oxide has previously been shown to inhibit purified bovine catalase activity in vitro (Brown 1995b). Nitric oxide donors (SNAP, Deta-NO) have also been shown to inhibit catalase activity in a rat glial cell line (Dobashi et al. 1997), human ovarian cancer cells (Farias-Eisner et al. 1996), endothelial cells (Hashida et al. 2000) and in MRL-lpr/lpr mice prone to autoimmune disease (Keng et al. 2000).

Catalase-overexpressing RINm5F cells generated more nitrite compared with control RIN cells after cytokine treatment in this study. This is consistent with their higher levels of nerve factor $\kappa \mathrm{B}$ activity (Martins et al. 2001). Most nitric oxide is converted to nitrite in aqueous solutions within seconds (Halliwell \& Gutteridge 1999); nitrite readily reacts with superoxide $\left(\mathrm{O}_{2}{ }^{-}\right)$to form nitrate (Kelm 1999) or with hydrogen peroxide to produce peroxynitrite (Halliwell \& Gutteridge 1999). RIN-Cat cells should contain a lower concentration of hydrogen peroxide and therefore be better protected from formation of peroxynitrite from hydrogen peroxide and nitrite compared with RINm5F cells. We found that the high production of nitric oxide after treatment with cytokines or Deta-NO was sufficient also to reduce the high levels of catalase activity in the catalase-overexpressing RINm5F cells, and this occurred to a similar degree as in RINm5F cells. Catalase activity was further inhibited by three cytokines vs IL-1 $\beta$ on its own but we measured no significant increase in nitrite plus nitrate - this may be explained by our carrying out treatments separately, those specifically designed to measure nitrite plus nitrate being in nitrate-free MEM, rather than RPMI medium, used when activity assays were performed.

The catalase assay could not discriminate between lowering of enzyme activity per se or a decrease in catalase protein or mRNA. There are few other reports on catalase protein regulation in insulin-producing cells - primary rat islet catalase protein levels were undetectable by Western blotting and activity is significantly lower than in rat liver (Tiedge et al. 1997). Using Western blotting, we found expression of catalase in RINm5F cells with a different antibody more clearly than previously (see Tiedge et al. 1997). Catalase expression was not altered by cytokines or nitric oxide donor treatments in our study. De novo synthesis of catalase protein was not found to be altered by cytokines or nitric oxide in normal rat islets (John et al. 2000) but was found to be upregulated in diabetes-prone $\mathrm{BB}$ rat islets cultured with IL-1 $\beta$ (Sparre et al. 2002). In our study, we found that catalase mRNA was not decreased by treatment with cytokines or nitric oxide, consistent with results elsewhere (Cardozo et al. 2001a).

The inhibitory effect of nitric oxide on catalase activity in insulin-producing cells was reversible after a short time exposure. This may be due to a breaking down of nitric oxide by catalase which has been reported in the presence of hydrogen peroxide in vitro (Brown 1995b). Nitric oxide binds to the iron in the catalase haem groups (Brown 1995a) and competition with hydrogen peroxide for these binding sites may lead to increased accumulation of hydrogen peroxide within cells. Nitric oxide also inhibits cytochrome oxidase in mitochondria, which leads to decreased ATP and leakage of free radicals, leading to further production of hydrogen peroxide (Brown \& Borutaite 1999). Nitric oxide and hydrogen peroxide therefore might work synergistically in cell killing. 
Rat islets are often more susceptible to injury compared with human islets (Eizirik et al. 1994). Modulation of the levels of catalase activity may alter the susceptibility of $\beta$-cells to cytokine or free radical attack in different species. Previous studies have indicated that rodent pancreatic islets contain low levels of catalase activity compared with that in other rodent organs (Grankvist et al. 1981, Tiedge et al. 1997) and compared with that in human islets (Welsh et al. 1995, Benhamou et al. 1998). Rat islet responses to nitric oxide donors were different in the short term compared with those of human islets; however, after 48-h culture treatment islet function was similarly decreased in the two species (Eizirik et al. 1996).

Catalase overexpression in cell lines (Tiedge et al. 1997) and in rat, porcine and human islets of Langerhans (Benhamou et al. 1998) has been found to improve the defence of these insulin-producing cells against cytokine and reactive oxygen damage. Catalase-overexpressing RINm5F cells (RIN-Cat) were found to be ten times more resistant against hydrogen peroxide toxicity (Tiedge et al. 1997) and $30-50 \%$ more resistant against the nitric oxide and reactive oxygen species - donors (SIN-1 and SNAP) compared with control RINm5F cells (Tiedge et al. 1999). Interestingly, RIN-Cat cells were not more resistant than control RINm5F cells against killing by the pure nitric oxide donor, Deta-NO (Tiedge et al. 1999). The catalaseoverexpressing RINm5F cells also showed higher viability after cytokine treatment with a combination of IL- $1 \beta$, TNF- $\alpha$, and IFN- $\gamma$, but were not more resistant against IL- $1 \beta$ treatment on its own compared with unmodified RINm5F cells (Lortz et al. 2000), suggesting that IL-1 $\beta$ induces mainly nitric oxide production and combined cytokines give rise to reactive oxygen species in insulinproducing cells.

In conclusion, cytokine treatment induces nitric oxide which inhibits catalase activity in insulinproducing cells; the inhibition is reproduced by exogenous nitric oxide and both treatments inhibit activity in cells where catalase has been overexpressed. This inhibition may confer added susceptibility to cytokine-induced toxicity. However, as the effects of cytokines and nitric oxide on catalase activity are reversible in the absence of these agents, and are not inhibitory at the level of protein expression or catalase gene expression in $\beta$-cells, increased expression of catalase may help the cell to survive deleterious effects of local high concentrations of free radicals.

\section{Acknowledgements}

This work was supported in part by the Concerted Action Islet Research European Network in the BIOMED 2 programme of the European Union. It was supported in part by the Biotechnology and Biological Sciences Research Council through an industrial CASE studentship to N B. We thank Dr Sue Swift and colleagues at the University of Leicester for provision of human islets. The work formed part of the $\mathrm{PhD}$ thesis of $\mathrm{LAS}$. We also thank the Swedish Diabetes Association and the Swedish Medical Society.

\section{References}

Barthwal MK, Srivastava N, Nag D, Seth PK, Srimal RC \& Dikshit M 2000 Antioxidant levels in the rat brain after nitric oxide synthase inhibition: a preliminary report. Redox Report 5 75-79.

Benhamou PY, Moriscot C, Richard MJ, Beatrix O, Badet L, Pattou F, Kerr-Conte J, Chroboczek J, Lemarchand P \& Halimi S 1998 Adenovirus-mediated catalase gene transfer reduces oxidant stress in human, porcine and rat pancreatic islets. Diabetologia $\mathbf{4 1}$ 1093-1100.

Borg LAH, Cagliero E, Sandler S, Welsh N \& Eizirik DL 1992 Interleukin- $1 \beta$ increases the activity of superoxide dismutase in rat pancreatic islets. Endocrinology 130 2851-2857.

Bradford MM 1976 A rapid and sensitive method for the quantification of microgram quantities of protein utilizing the principle of protein-dye binding. Analytical Biochemistry 72 248-254.

Brown GC 1995a Nitric oxide regulates mitochondrial respiration and cell functions by inhibiting cytochrome oxidase. FEBS Letters 369 136-139.

Brown GC $1995 b$ Reversible binding and inhibition of catalase by nitric oxide. European Fournal of Biochemistry 232 188-191.

Brown GC \& Borutaite V 1999 Nitric oxide, cytochrome c and mitochondria. Biochemical Society Symposium 66 17-25.

Cardozo AK, Heimberg H, Heremans Y, Leeman R, Kutlu B, Kruhoffer M, Orntoft T \& Eizirik D $2001 a$ A comprehensive analysis of cytokine-induced and nuclear factor-kappa B-dependent genes in primary rat pancreatic beta-cells. Fournal of Biological Chemistry 276 48879-48886.

Cardozo AK, Kruhøffer M, Leeman R, Ørntoft T \& Eizirik DL $2001 b$ Identification of novel cytokine-induced genes in pancreatic $\beta$-cells by high-density oligonucleotide arrays. Diabetes 50 909-920.

Chomczynski P \& Sacchi N 1987 Single-step method of RNA isolation by acid guanidinium thiocyanate-phenol-chloroform extraction. Analytical Biochemistry 162 156-159.

Dobashi K, Pahan K, Chahal A \& Singh I 1997 Modulation of endogenous antioxidant enzymes by nitric oxide in rat C6 glial cells. Fournal of Neurochemistry 68 1896-1903.

Eizirik DL \& Mandrup-Poulsen T 2001 A choice of death - the signal-transduction of immune-mediated beta-cell apoptosis. Diabetologia 44 2115-2133.

Eizirik DL, Pipeleers DG, Ling Z, Welsh N, Hellerström C \& Andersson A 1994 Major species differences between humans and rodents in the susceptibility to pancreatic $\beta$-cell injury. PNAS 91 9253-9256.

Eizirik DL, Delaney CA, Green MHL, Cunningham JM, Thorpe JR, Pipeleers DG, Hellerström C \& Green IC 1996 Nitric oxide donors decrease the function and survival of human pancreatic islets. Molecular and Cellular Endocrinology 118 71-83. 
Farias-Eisner R, Chaudhuri G, Aeberhard E \& Fukuto JM 1996 The chemistry and tumoricidal activity of nitric oxide/hydrogen peroxide and the implications to cell resistance/susceptibility. Fournal of Biological Chemistry $2716144-6151$.

Garvey EP, Oplinger JA, Furfine ES, Kiff RJ, Laszlo F, Whittle BJR \& Knowles RG 1997 1400W is a slow, tight binding, and highly selective inhibitor of inducible nitric-oxide synthase in vitro and in vivo. Fournal of Biological Chemistry 272 4959-4963.

Gazdar AF, Chick WL, Oie HK, Sims HL, King DL, Weir GC \& Lauris V 1980 Continuous, clonal insulin- and somatostatinsecreting cell lines established from a transplantable rat islet cell tumor. PNAS 77 3519-3523.

Grankvist K, Marklund SL \& Täljedal I-B 1981 CuZn-superoxide dismutase, Mn-superoxide dismutase, catalase and glutathione peroxidase in pancreatic islets and other tissues in the mouse. Biochemical fournal 199 393-398.

Green LC, Wagner DA, Glogowski J, Skipper PL, Wishnok JS \& Tannenbaum SR 1982 Analysis of nitrate, nitrite and $\left[{ }^{15} \mathrm{~N}\right]$ nitrate in biological fluids. Analytical Biochemistry 126 131-138.

Hadjivassiliou V, Green MHL, James RFL, Swift SM, Clayton HA \& Green IC 1998 Insulin secretion, DNA damage and apoptosis in human and rat islets of Langerhans following exposure to nitric oxide, peroxynitrite and cytokines. Nitric Oxide - Biology and Chemistry 2 429-441.

Hadjivassiliou V, Green MHL \& Green IC 2000 Immunomagnetic purification of beta cells from rat islets of Langerhans. Diabetologia 43 1170-1177.

Halliwell B \& Gutteridge JMC 1999 The chemistry of free radicals and related 'reactive species'. In Free Radicals in Biology and Medicine, pp. 82-104. Oxford University Press: Oxford.

Hashida K, Sasaki K \& Makino N 2000 Interactions of nitric oxide and oxygen in cytotoxicity: proliferation and antioxidant enzyme activities of endothelial cells in culture. Free Radical Research 33 147-156.

Hoorens A, Strangé G, Pavlovic D \& Pipeleers D 2001 Distinction between interleukin-1-induced necrosis and apoptosis of islet cells. Diabetes 50 551-557.

Hussain MJ, Peakman M, Gallati S, Lo SSS, Hawa M, Viberti GC, Watkins PJ, Leslie RDG \& Vergani D 1996 Elevated serum levels of macrophage-derived cytokines precede and accompany the onset of IDDM. Diabetologia 39 60-69.

Johansson LH \& Borg LAH 1988 A spectrophotometric method for determination of catalase activity in small tissue samples. Analytical Biochemistry 174 331-336.

John NE, Andersen HU, Fey SJ, Mose Larsen P, Roepstorff P, Larsen MR, Pociot F, Karlsen AE, Nerup J, Green IC \& Mandrup-Poulsen T 2000 Cytokine- or chemically derived nitric oxide alters the expression of proteins detected by two-dimensional gel electrophoresis in neonatal rat islets of Langerhans. Diabetes 49 1819-1829.

Kelm M 1999 Nitric oxide metabolism and breakdown. Biochimica et Biophysica Acta Bioenergetics 1411 273-289.

Keng T, Privalle CT, Gilkeson GS \& Weinberg JB 2000 Peroxynitrite formation and decreased catalase activity in autoimmune MRL-lpr/lpr mice. Molecular Medicine 6 779-792.

Lakey JR, Suarez-Pinzon WL, Strynadka K, Korbutt GS, Raj RV, Mabley JG, Szabo C \& Rabinovitch A 2001 Peroxynitrite is a mediator of cytokine-induced destruction of human pancreatic islet beta cells. Laboratory Investigation 81 1683-1692.

Laychock SG 1998 Rat pancreatic islets and RINm5F cell responses to epiandrosterone, dehydroepiandrosterone and interleukin-1 beta. Biochemical Pharmacology 55 1453-1464.

Lenzen S, Drinkgern J \& Tiedge M 1996 Low antioxidant enzyme gene expression in pancreatic islets compared with various other mouse tissues. Free Radical Biology and Medicine 20 463-466.

Lindsay RM, Peet RS, Wilkie GS, Rossiter SP, Smith W, Baird JD \& Williams BC 1997 In vivo and in vitro evidence of altered nitric oxide metabolism in the spontaneously diabetic, insulin-dependent BB/Edinburgh rat. British Fournal of Pharmacology 120 1-6.
Lortz S, Tiedge M, Nachtwey T, Karlsen AE, Nerup J \& Lenzen S 2000 Protection of insulin-producing RINm5F cells against cytokine-mediated toxicity through overexpression of anti-oxidant enzymes. Diabetes 49 1123-1130.

Mabley JG, Belin VD, John NE \& Green IC 1997 Insulin-like growth factor 1 reverses interleukin- $1 \beta$ inhibition of insulin secretion, induction of nitric oxide synthase and cytokine-mediated apoptosis in rat islets of Langerhans. FEBS Letters 417 235-238.

Mabley JG, Pacher P, Southan GJ, Salzman AL \& Szabo C 2002 Nicotine reduces the incidence of type I diabetes in mice. Fournal of Pharmacology and Experimental Therapeutics 300 876-881.

Martins AKA, Lenzen S, Tiedge M \& Lortz S 2001 Investigation of cytokine-activated transcription factors in RIN m5F cells overexpressing antioxidative enzymes by reporter gene and gel shift assays. Diabetologia 44155.

Mauricio D \& Mandrup-Poulsen T 1998 Apoptosis and the pathogenesis of IDDM. A question of life and death. Diabetes 47 1537-1543.

Mose Larsen P, Fey SJ, Larsen MR, Nawrocki A, Andersen HU, Kähler H, Heilmann C, Voss MC, Roepstorff P, Pociot F, Karlsen AE \& Nerup J 2001 Proteome analysis of interleukin- $1 \beta$-induced changes in protein expression in rat islets of Langerhans. Diabetes $\mathbf{5 0}$ 1056-1063.

Pociot F, Lorenzen T \& Nerup J 1993 A manganese superoxide dismutase (SOD2) gene polymorphism in insulin-dependent diabetes mellitus. Disease Markers 11 267-274.

Rabinovitch A, Suarez WL, Thomas PD, Strynadka K \& Simpson I 1992 Cytotoxic effects of cytokines on rat islets: evidence for involvement of free radicals and lipid peroxidation. Diabetologia 35 409-413.

Rotzinger S, Aragon CMG, Rogan F, Amir S \& Amit Z 1995 The nitric oxide synthase inhibitor $\mathrm{N}^{\mathrm{w}}$-nitro-L-arginine methylester attenuates brain catalase activity in vitro. Life Sciences 56 1321-1324.

Southern C, Schulster D \& Green IC 1990 Inhibition of insulin secretion by interleukin- $1 \beta$ and tumour necrosis factor-a via an L-arginine-dependent nitric oxide generating mechanism. FEBS Letters 276 42-44.

Sparre T, Christensen UB, Larsen PM, Fey SJ, Wrzesinski K, Roepstorff P, Mandrup-Poulsen T, Pociot F, Karlsen AE \& Nerup J 2002 IL-1 beta induced protein changes in diabetes prone BB rat islets of Langerhans identified by proteome analysis. Diabetologia 45 1550-1561.

Suarez-Pinzon WL, Szabó C \& Rabinovitch A 1997 Development of autoimmune diabetes in NOD mice is associated with the formation of peroxynitrite in pancreatic islet $\beta$-cells. Diabetes $\mathbf{4 6}$ 907-911.

Suarez-Pinzon WL, Mabley JG, Strynadka K, Power RF, Szabo C \& Rabinovitch A 2001 An inhibitor of inducible nitric oxide synthase and scavenger of peroxynitrite prevents diabetes development in NOD mice. Fournal of Autoimmunity 16 449-455.

Tiedge M, Lortz S, Drinkgern J \& Lenzen S 1997 Relation between antioxidant enzyme gene expression and antioxidative defense status of insulin-producing cells. Diabetes 46 1733-1742.

Tiedge M, Lortz S, Munday R \& Lenzen S 1999 Protection against the co-operative toxicity of nitric oxide and oxygen free radicals by overexpression of antioxidant enzymes in bioengineered insulin-producing RINm5F cells. Diabetologia 42 849-855.

Welsh N, Margulis B, Håkan Borg L, Wiklund HJ, Saldeen J, Flodström M, Mello MA, Andersson A, Pipeleers DG, Hellerström C \& Eizirik DL 1995 Differences in the expression of heat-shock proteins and antioxidant enzymes between human and rodent pancreatic islets: implications for the pathogenesis of insulin-dependent diabetes mellitus. Molecular Medicine 1 806-820.

Xia Y \& Zweier JL 1997 Superoxide and peroxynitrite generation from inducible nitric oxide synthase in macrophages. PNAS 94 6954-6958.

Received in final form 14 July 2003

Accepted 13 August 2003 